\title{
Unbundling Transaction Cost Components in Building Information Modeling Adoption Procurement
}

\author{
Toh Ka Bean, Fara Diva Mustapa, Muzani Mustapa
}

\begin{abstract}
Building information modeling (BIM) adoption is an emerging trend in Malaysian construction industry. BIM is expected to bring better project performance and address the various construction dilemmas stemmed from construction disputes. Construction disputes has been associated with high transaction costs, which subsequently increase overall project costs. Hence, BIM has been adopted in project procurement to address construction disputes for better project performance. Studying the transaction costs in BIM adoption procurement is deemed beneficial particularly when the ambiguity of a project performance is high. This is especially true when the number of projects adopting BIM is still comparatively small to ascertain the benefits of BIM. Transaction cost economics (TCE) is a theory and methodology for relatively evaluating the cost-effectiveness of institutional arrangements in managing transaction, and therefore, studying TCE in BIM adoption procurement can be beneficial. Such an effort can improve the understanding of the benefits of the transactions made. Previous research has managed to conclude that the traditional procurement resulted in higher transaction costs compared to the design-and-build procurement. Hence, this study attempts to identify the transaction costs in BIM adoption procurement. A systematic literature review was performed to investigate the TCE in procurement to profile the transaction costs and its components in BIM adoption procurement. The outcome of the systematic structured literature is a conceptual framework combining the "RIBA Plan of Work with BIM Overlay" developed by RICS with a refined transaction cost components categorisation. The framework is further classified into pre-contract and post-contract transaction cost components specifying the fixed and variable components, and either visible or hidden. It is believed that the unbundling of the components of transaction cost in BIM adoption procurement could provide a solid foundation in developing a guideline for industry players to better understand, apply, and manage BIM adoption procurement.
\end{abstract}

Index Terms: Transaction cost components; Building Information Modeling (BIM); Procurement; Construction industry

\section{INTRODUCTION}

The adoption of building information modeling (BIM) is an emerging trend in the Malaysian construction industry

Revised Manuscript Received on September 22, 2019

Toh Ka Bean, Department of Quantity Surveying, Universiti Teknologi Malaysia, Johor Bahru, Johor, 81310 MALAYSIA., kbtoh2@live.utm.my

Fara Diva Mustapa, Department of Quantity Surveying, Universiti Teknologi Malaysia, Johor Bahru, Johor, 81310 MALAYSIA.

Muzani Mustapa, Department of Quantity Surveying, Universiti Teknologi Malaysia, Johor Bahru, Johor, 81310 MALAYSIA.
$(1,2)$. BIM is said to be able to benefit construction projects in many ways including minimising disputes, due to its ability to detect design clashes $(3,4)$ and problems at the early project stage (5). An interesting and significant report by Arcadis in 2016 (6) highlights a dispute value amounting to RM 261 millions in 2015. The data indicates that the Malaysian construction industry has experienced issues stemmed from construction disputes, such as prolonged project duration $(6,7)$, increased project costs (9), and high transaction costs (TCs) (10). Such drawbacks are further noted by Izzat Ratna (2018) (11), who claimed that more than 700 dispute cases have been filed in Asian International Arbitration Centre (AIAC) in 2017, amounting approximately to RM 1.4 billion, which exceeded the record in 2016. In response to the issue, BIM was introduced and adopted, and this alternative improved procurement method is believed to be able to reduce construction disputes and subsequently reduce project transaction costs hence overall project costs.

BIM adoption in Malaysia is considered relatively new and therefore, its performance in assisting projects towards success is yet to be justified. This is where studying TCs within BIM adoption procurement is beneficial due to the ambiguities arising in regard to the performance of BIM adoption (12). Understanding the transaction cost economics (TCE) inherent in such projects allows industry players to have a clearer illustration of the causes of disputes and benefits of any transaction or economic exchange made (13).

Many researchers have investigated the relationship between TCs and various procurement types, such as traditional (14), design and build $(14,15)$, and the public-private-partnership (PPP) procurement $(16,17)$. One research by M. Rajeh (2014) (14) highlights that the TCs in traditional procurement is higher compared to those in design-and-build procurement. Another case study on PPP concludes the benefits of studying transaction costs within procurement particularly in determining the variables that affect transaction costs as well as suggestions made in managing projects (18). It was also found that studying TCE can benefits a project by lowering the transaction costs (16).

Therefore, studying the transaction costs within a procurement will be beneficial to determine the transaction costs and suggest solutions to effectively manage BIM adoption procurement. 
Hence, this paper attempts to investigate the components of TCs in BIM adoption procurement via a systematic structured literature review. The identification of TCE components was carried out by studying the activities involved in BIM adoption procurement particularly by utilising the "RIBA Plan of Work with BIM overlay" prepared by the RICS (19). TCE components within the "RIBA Plan of Work with BIM overlay" was further elaborated by the following categorisation: the pre and post contract components; fixed and variable components; and either the componentsare visible or hidden.

\section{LITERATURE REVIEW}

\section{A. Building Information Modeling (BIM)}

BIM is a technology that provides a platform for industry players to work in collaborative means by sharing and updating information and knowledge in a similar platform without depending on venue and time $(4,20)$. BIM also assists industry players in making decision throughout a project life cycle (21) and provides the revolution on design ideas and the working method of construction projects (22).

BIM can prevent construction disputes (5), which is the root cause of high transaction costs. BIM able to search and review conflicts within a project at early phases. Such benefit is evidenced by an American project which employed BIM successfully. In this project, BIM was able to review procedure at project early phase by identifying as many as 7213 conflicts and 257 constructability issues. In comparison, only 1 conflict and 6 constructability issues could be detected at the early phase of a project procured by the traditional method (5). Hence, it can be deduced that BIM adoption in project procurement can facilitate detecting potential problems at the project early stage in comparison with the traditional procurement.

BIM technology involves three levels of revolutions from level 1 to level 3. Level 1 of BIM or lonely BIM involves no collaboration among industry players in that a single party would work alone in utilising the benefits of a BIM model. Level 2 of BIM involves an integration of working among all key members in producing 3D information models. It is not compulsory for the co-existence of the models to become a single model. At level 3 of BIM, the requirement of software interoperability is essential in increasing information value. It allows, among others, the implementation of design analysis towards the environmental performance at early stage, cost models derivation at speedy duration, safety and health analysis regarding building construction, and maintenance to work at the same time with design (19).

\section{B. Transaction Cost Economics (TCE)}

Transaction cost economics is a theory and methodology for relatively assessing the cost-effectiveness of institutional arrangements in managing transaction (23). TCE involves mutual relationship between human factor and environmental factor. Human factor refers to the behaviours of construction parties, such as the owner and contractor; environmental factor refers to the surrounding and mechanism of transaction as well as project management matter (24). Study TCE allows parties to have better understanding of the unseen costs associated with pre-contract and post-contract of a project (14).

TCs are the costs that arised from the transactional activities in the construction industry (10). It involves (i) the costs of searching and information; (ii) the costs of bargaining and decision; and (iii) the costs of policing and enforcements (25). TCs can be classified into variables or fixed components, and the components are either visible (transparent) or hidden (nontransparent). Variable transaction cost components, which form the major parts of overall transaction costs, change according to the investment decision implementation and are dependent on the strategy of implementation. Fixed components refer to the components which are independent of the implementation strategy. Visible (transparent) transaction cost components refer to the components whose costs are with known fee structure, such as the percentage of realised trading profit or traded value (e.g., fees, commissions, taxes and spreads). Hidden (nontransparent) transaction cost components refer to the components with unknown fee structure which should be consciously noted by the parties involved for value-added purpose to the implementation procedure (26).

In normal procurement, the pre-contract transaction costs involve initiation costs and the costs involved in preliminary design, bargaining and contracting, as well as feasibility studies. While post-contract transaction costs consist of the costs of monitoring and control, dispute resolution and implementation costs (10).

The application of TCE concept is expected to improve project performance as it facilitates better contractual protocols, stimulate long-term strategic methods of procurement, improve cost estimation, and determine most workable contractual ways under particular situation, which can facilitate the improvement of the whole procurement process. However, it is always too difficult, subjective, and broad to quantify and assess transaction costs $(14,18,27,28)$.

\section{METHODOLOGY/MATERIALS}

A systematic literature review was adopted in this study to assist the researcher in profiling the conceptual framework as indicated in Figure 1.

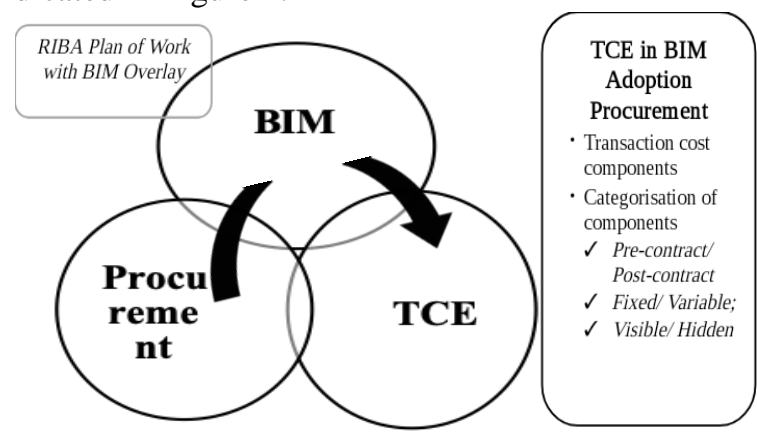

Fig 1. Structured Literature Review Framework Adopted in This Study 
As indicated in Figure 1, the research focuses on three areas: building information modeling (BIM), transaction cost economics (TCE), and procurement methods. The main focuses of this paper are on BIM and TCE. In this context, the definition, benefits, and important information related to the procurement by means of BIM and TCE were carefully studied and reviewed. Literature related to procurement was reviewed in order to garner basic understanding on the various procurement types applied within the construction industry. The systematic literature review on BIM provided better understanding on the implementation practices and benefits of BIM in addressing disputes, and the systematic literature review on TCE allowed better understanding on the causes of disputes and benefits of making any transaction or economic exchange in the construction industry.

This framework provided a solid foundation to study TCE within BIM adoption procurement. The measure thus can eventually be useful in determining the components of transaction costs and their categorisation in BIM adoption procurement.

\section{RESULTS AND FINDINGS}

Table 1 depicts the conceptual framework of the components of TCs in BIM adoption procurement based on pre-contract and post-contract categorisation. The conceptual framework was based, drafted, and refined by referring to the "RIBA Plan of Work with BIM Overlay" by the RICS (19). The components are further classified into (i) pre-contract or post-contract; (ii) fixed or variable; and (iii) visible (transparent) or hidden (non-transparent) by referring to some previous research works regarding TCs in project procurement $(10,14,26)$.

Table 1. BIM Adoption Procurement's Transaction Cost Components Framework and Its Categorisation

\begin{tabular}{|c|c|c|c|c|}
\hline \multirow{4}{*}{$\begin{array}{c}\text { BIM } \\
\text { Adoptio } \\
\text { n } \\
\text { Procure } \\
\text { ment }\end{array}$} & \multirow{4}{*}{$\begin{array}{c}\text { Projec } \\
\text { t } \\
\text { Phase } \\
\text { s }\end{array}$} & \multirow{4}{*}{ 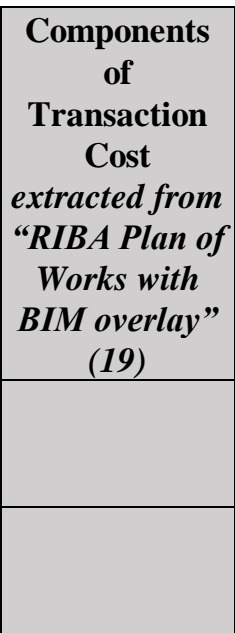 } & \multicolumn{2}{|c|}{$\begin{array}{c}\text { Categorisation of } \\
\text { Transaction Cost } \\
\text { Components }\end{array}$} \\
\hline & & & & \\
\hline & & & \multicolumn{2}{|c|}{ Anticipated } \\
\hline & & & $\begin{array}{c}\text { Fixed/ } \\
\text { Variable }\end{array}$ & \begin{tabular}{|c} 
Visible \\
$/$ \\
Hidden \\
\end{tabular} \\
\hline $\begin{array}{l}\text { Pre-con } \\
\text { tract } \\
\text { Transac } \\
\text { tion } \\
\text { Cost } \\
\text { Compo } \\
\text { nents }\end{array}$ & \begin{tabular}{|l|} 
Appra \\
isal, \\
Desig \\
n \\
Brief
\end{tabular} & \begin{tabular}{|l|} 
- Provide \\
advice to client \\
on BIM \\
purpose \\
(implications \\
and \\
advantages). \\
Make \\
agreement on \\
BIM's level \\
\end{tabular} & Variable & Hidden \\
\hline
\end{tabular}

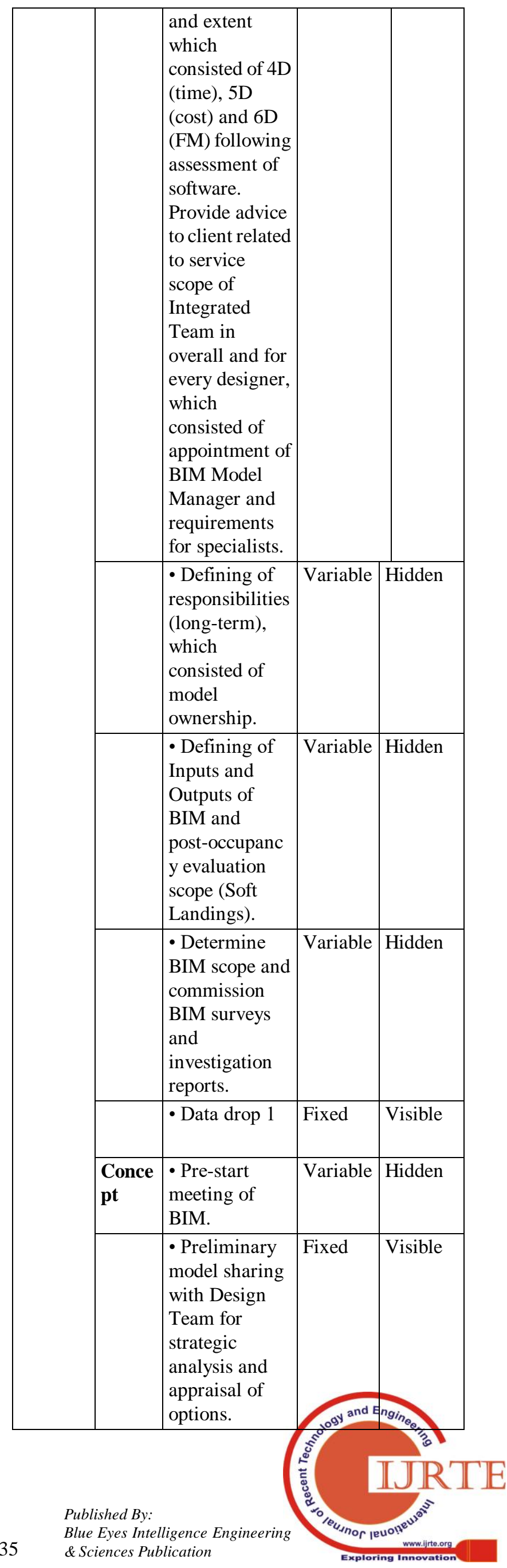




\begin{tabular}{|c|c|c|c|}
\hline & $\begin{array}{l}\text { - Utilisation of } \\
\text { BIM data for } \\
\text { analysis of } \\
\text { environmental } \\
\text { performance } \\
\text { and area. }\end{array}$ & Fixed & Visible \\
\hline & $\begin{array}{l}\text { - Determine } \\
\text { elements of key } \\
\text { model (e.g. } \\
\text { prefabricated } \\
\text { component) } \\
\text { and establish } \\
\text { parametric } \\
\text { objects at } \\
\text { concept level } \\
\text { for all major } \\
\text { elements. }\end{array}$ & Variable & Visible \\
\hline & $\begin{array}{l}\text { - Allow } \\
\text { accessing to } \\
\text { BIM data by } \\
\text { design team. }\end{array}$ & Fixed & Visible \\
\hline & $\begin{array}{l}- \text { Make } \\
\text { agreement on } \\
\text { extent of } \\
\text { performance } \\
\text { specified work. }\end{array}$ & Variable & Hidden \\
\hline & - Data drop 2 & Fixed & Visible \\
\hline \begin{tabular}{|l|} 
Desig \\
n \\
Devel \\
opme \\
nt, \\
Techn \\
ical \\
Desig \\
n \\
\end{tabular} & $\begin{array}{l}\text { - Sharing and } \\
\text { integration of } \\
\text { data for design } \\
\text { coordination } \\
\text { and detailed } \\
\text { analysis which } \\
\text { consisted of } \\
\text { data links } \\
\text { between } \\
\text { models. }\end{array}$ & Fixed & Visible \\
\hline & $\begin{array}{l}\text { - Integration/ } \\
\text { development of } \\
\text { generic/ } \\
\text { bespoke design } \\
\text { components. }\end{array}$ & Variable & Visible \\
\hline & $\begin{array}{l}\text { - Utilisation of } \\
\text { BIM data for } \\
\text { analysis of } \\
\text { environmental } \\
\text { performance } \\
\text { and area. }\end{array}$ & Fixed & Visible \\
\hline & $\begin{array}{l}\text { - Sharing of } \\
\text { data for } \\
\text { coordination of } \\
\text { design, } \\
\text { technical } \\
\text { analysis and } \\
\text { addition of } \\
\text { specification } \\
\text { data. }\end{array}$ & Fixed & Visible \\
\hline & - Data export & Fixed & Visible \\
\hline
\end{tabular}

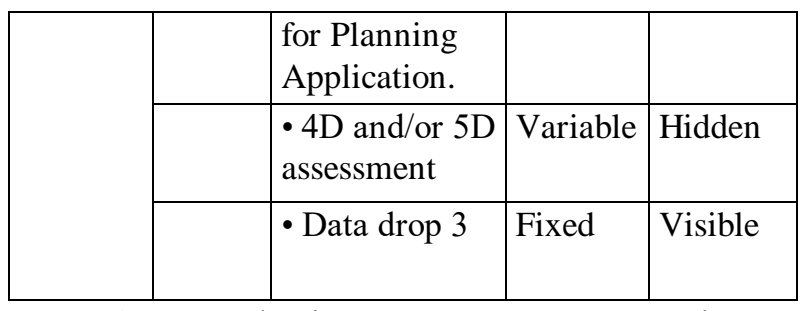

Table 2. BIM Adoption Procurement's Transaction Cost Components Framework and Its Categorisation (Con't)

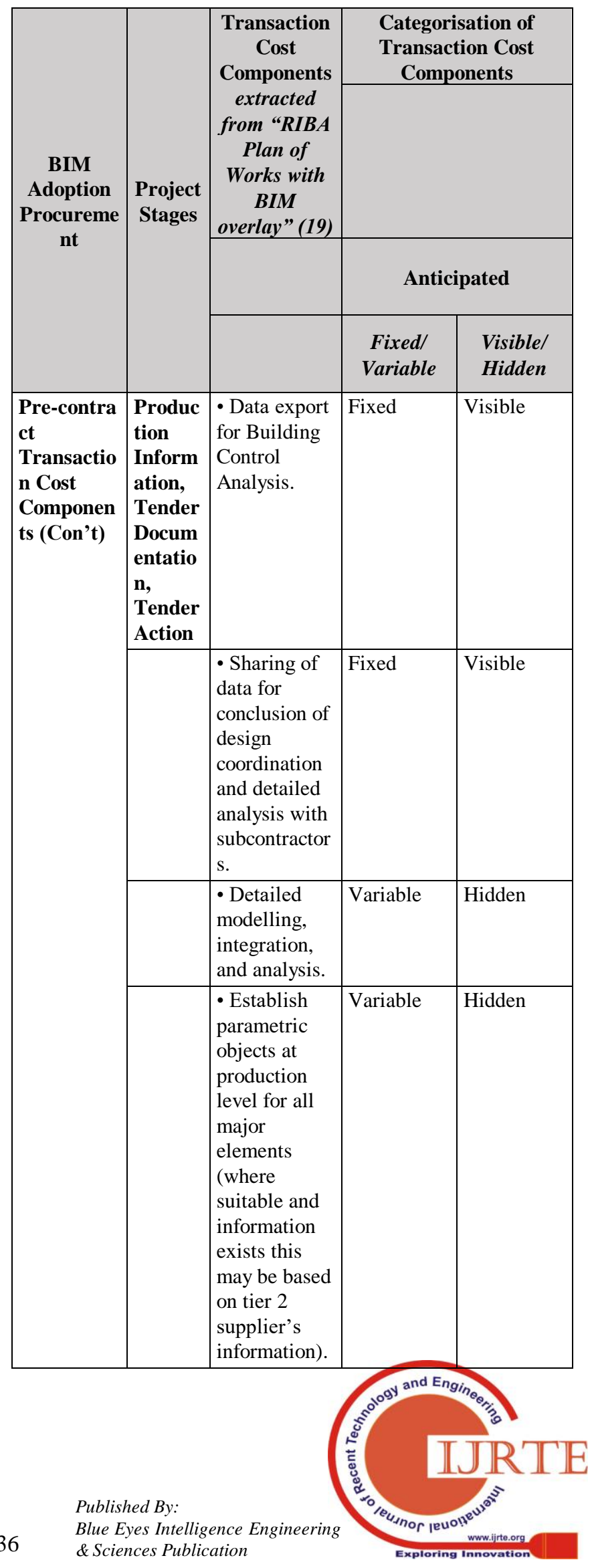




\begin{tabular}{|c|c|c|c|c|}
\hline & & $\begin{array}{l}- \text { Embed } \\
\text { specification } \\
\text { to model. }\end{array}$ & Fixed & Visible \\
\hline & & $\begin{array}{l}\text { - Model final } \\
\text { review and } \\
\text { sign off. }\end{array}$ & Variable & Hidden \\
\hline & & $\begin{array}{l}\text { - Allow } \\
\text { accessing to } \\
\text { BIM model } \\
\text { by } \\
\text { contractor(s). }\end{array}$ & Fixed & Visible \\
\hline & & \begin{tabular}{|l} 
- Integration \\
of \\
subcontractor \\
performance \\
specified \\
work model \\
information \\
into BIM \\
model data.
\end{tabular} & Fixed & Visible \\
\hline & & $\begin{array}{l}\text { - Reviewing } \\
\text { with } \\
\text { contractor the } \\
\text { construction } \\
\text { sequencing } \\
\text { (4D). }\end{array}$ & Variable & Hidden \\
\hline & & - Data drop 4 & Fixed & Visible \\
\hline $\begin{array}{l}\text { Post-contr } \\
\text { act } \\
\text { Transactio } \\
\text { n Cost } \\
\text { Componen } \\
\text { ts }\end{array}$ & \begin{tabular}{|l|} 
Mobilis \\
ation, \\
Constr \\
uction \\
to \\
Practic \\
al \\
Compl \\
etion
\end{tabular} & $\begin{array}{l}\text { - Make } \\
\text { agreement on } \\
\text { 'Soft } \\
\text { Landings' } \\
\text { timing and } \\
\text { scope. }\end{array}$ & Variable & Hidden \\
\hline & & $\begin{array}{l}\text { Co-ordination } \\
\text { and releasing } \\
\text { of 'End of } \\
\text { Construction' } \\
\text { BIM record } \\
\text { model data. }\end{array}$ & Variable & Hidden \\
\hline & & $\begin{array}{l}\text { - Utilisation } \\
\text { of } 4 \mathrm{D} / 5 \mathrm{D} \\
\text { BIM data for } \\
\text { administratio } \\
\mathrm{n} \text { of contract. }\end{array}$ & Fixed & Visible \\
\hline & & - Data drop 5 & Fixed & Visible \\
\hline & \begin{tabular}{|l|} 
Post \\
Practic \\
al \\
Compl \\
etion, \\
Model \\
Mainte \\
nance \\
\& \\
Develo \\
pment
\end{tabular} & $\begin{array}{l}\text { FM BIM } \\
\text { model data } \\
\text { issued as } \\
\text { asset changes } \\
\text { are made. }\end{array}$ & Fixed & Visible \\
\hline & & $\begin{array}{l}\text { - Study of } \\
\text { parametric }\end{array}$ & Variable & Hidden \\
\hline
\end{tabular}

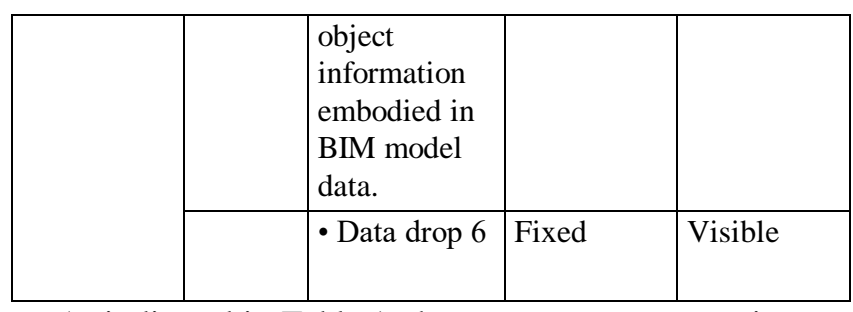

As indicated in Table 1, the pre-contract transaction cost components include the components that incur transaction costs within the appraisal and design brief stage until the tender action stage. For instance, during a pre-contract conception stage, a "BIM pre-start meeting" is believed to involve TCs such as the costs of searching for information, and the costs of bargaining and decision for smooth implementation and best results of the whole meeting. Therefore, "BIM pre-start meeting" is considered as one of the pre-contract transaction cost components because it may incur or affect the transaction costs of the project. Post-contract transaction cost components include the components that incur transaction costs within the mobilisation and construction stage until the post practical, model maintenance, and development stage.

The pre-contract and post-contract TC components are further classified into fixed or variable components and either visible or hidden. The anticipation of the transaction cost components categorisation is based on whether the components are dependent or independent on the project-related implementation strategies, and whether they are with known or unknown fee structure. For example, a post-contract transaction cost component on the "utilisation of 4D or 5D BIM data for the purpose of administering contract" during mobilisation, construction to practical completion stage is anticipated to fall into the category of fixed transaction cost component with visible costs. Because the BIM data are already determined and exist upon reaching the mobilisation, construction, to practical completion stage, the utilisation and retrieval of the existing data will not be affected by the implementation strategy of the project or incur any additional unknown fees; therefore, "utilisation of 4D or 5D BIM data for the purpose of administering contract" is considered as fixed and visible transaction cost components. The conceptual framework will be further verified and refined according to the dedicated components in the subsequent research phase via verification from BIM experts.

\section{CONCLUSION}

BIM adoption in project procurement is said to be able to reduce construction disputes, which are considered as one of the major contributors to increased transaction costs and subsequently overall project costs. The causes of disputes and benefits of transactions can be better understood by studying the transaction cost economics (TCE) within BIM adoption procurement. Studying the three underlying theories of BIM, TCE, and procurement could deduce the benefits on making transactions within BIM adoption procurement. 
Additionally, understanding the components of transaction costs in a BIM adoption procurement can facilitate better understanding and monitoring of the TCs involved in BIM adoption procurement.

In this paper, the transaction cost components are categorised into pre-contract components and post-contract components, either fixed or variable, and either visible or hidden. The conceptual framework of the transaction cost components was prepared as a reference for construction players to better understand the transaction costs, particularly the hidden costs, in BIM adoption procurement. The framework allows more detailed quantification of transaction costs in the subsequent research phase by providing a detailed breakdown of the transaction cost components based on pre- or post-contract, fixed or variable, and visible or hidden.

\section{ACKNOWLEDGEMENTS}

This research work is sponsored by UTM GUP: Vot No. Q.J130000.2621.14J24 and UTM Zamalah scholarship.

\section{REFERENCES}

[1] Suzila Mohd, Brahim J, Latiffi AA, Fathi MS, Harun AN. Developing Building Information Modelling (BIM) Implementation Model. Proc Int Conf Innov Manag. 2016;119-29.

[2] Salman A. Building Information Modeling (BIM): Trends, Benefits, Risks, and Challenges for the AEC Industry. Leadersh Manag Eng. 2011;11(Bazjanac 2006):241-52.

[3] Latiffi AA, Mohd S, Brahim J. Application of Building Information Modeling (BIM) in the Malaysian Construction Industry: A Story of the First Government Project. Appl Mech Mater [Internet]. 2015;773-774(March):943-8. Available from: https://www.scientific.net/AMM.773-774.943

[4] Sebastian R. Changing roles of the clients , architects and contractors through BIM. Eng Constr Archit Manag. 2014;18(2):176-87.

[5] Khoshnava SM, Ahankoob A. Potential Application of BIM in Construction Dispute and Conflict. Manag Constr Res Assoc (MiCRA) Postgrad Conf. 2006;178-84.

[6] Arcadis. Global Construction Disputes Report 2016. Contract Solut [Internet]. 2016;17. Available from: https://www.arcadis.com/media/3/E/7/\%7B3E7BDCDC-0434-4237-92 4F-739240965A90\%7DGlobal Construction Disputes Report 2016.pdf

[7] Kong AT, Gray J. Problems With Traditional Procurement in the Malaysian Construction Industry - a Survey. Proc Australas Univ Build Educ Assoc Annu Conf. 2006;2006:1-21.

[8] Kong AT. Traditional Procurement is too slow. 2000; (Hovet 1994):51-62.

[9] Jaffar N, Abdul Tharim AH, Shuib MN. Factors of conflict in construction industry: A literature review. Procedia Eng [Internet]. 2011;20:193-202. Available from: http://dx.doi.org/10.1016/j.proeng.2011.11.156

[10] Li H, Arditi D, Wang Z. Transaction costs incurred by construction owners. Eng Constr Archit Manag [Internet]. 2014;21(4):444-58. Available

http://www.emeraldinsight.com/doi/10.1108/ECAM-07-2013-0064

[11] Izzat Ratna. Construction Sector Sees A Higher Number of Dispute Cases. 2018;

[12] Talebi S. Rethinking the Project Development Process through Use of BIM. In: 2nd BIM International Conference on Challenges to Overcome. 2014. p. 1-19.

[13] Boudreau M-C, Watson RT, Chen AJW, Greiner M, Sclavos P. The Benefits of Transaction Cost Economics: The Beginning of A New Direction. In: Fifteenth European Conference on Information Systems, ECIS. University of St. Gallen; 2007. p. 1124-35.

[14] Rajeh M. Impacts of Procurement Systems on Transaction Costs: A Structural Equation Modelling Methodology. Proc 4th New Zeal Built Environ Res Symp. 2014;1829(2014):1-34.

[15] Rajeh MA, Tookey J, Rotimi J. Best procurement selection: development of a conceptual model based on transaction costs. Australas J Constr Econ Build - Conf Ser [Internet]. 2013;2(2):56. Available from: https://epress.lib.uts.edu.au/journals/index.php/AJCEB-Conference-Seri
es/article/view/3889\%0Ahttp://aut.researchgateway.ac.nz/handle/1029 $2 / 6031$

[16] De Schepper S, Haezendonck E, Dooms M. Understanding pre-contractual transaction costs for Public-Private Partnership infrastructure projects. Int J Proj Manag [Internet]. 2015;33(4):932-46. Available

http://linkinghub.elsevier.com/retrieve/pii/S0263786314001720

[17] Thomassen K, Vassb $\emptyset$ S, Solheim-Kile E, Lohne J. Public-Private Partnership: Transaction Costs of Tendering. Procedia Comput Sci [Internet]. 2016;100(1877):818-25. Available from: http://dx.doi.org/10.1016/j.procs.2016.09.230

[18] Ho SP, Tsui CW. The Transaction Costs of Public-Private Partnerships: Implications on PPP Governance Design. Lead 2009 Spec Conf Glob Governmance Proj Organiations, South Lake Tahoe, CA [Internet]. 2009;5-7. Available from: http://www.academiceventplanner.com/LEAD2009/papers/Ho_Tsui.pd $\mathrm{f}$

[19] Sinclair D. BIM Overlay to the RIBA Outline Plan of Work. RIBA London. 2012;(May):1-20.

[20] Sebastian R, Haak W, Vos E. BIM Application for Integrated Design and Engineering in Small- Scale Housing Development: A Pilot Project in The Netherlands. Futur Trends Archit Manag. 2009;161-71.

[21] NIBS NI of BS. National Building Information Modeling, Version 1: Part 1. Washington, DC.; 2007.

[22] Vysotskiy A, Makarov S, Zolotova J, Tuchkevich E. Features of BIM implementation using autodesk software. Procedia Eng [Internet]. 2015;117(1):1148-57. Available from: http://dx.doi.org/10.1016/j.proeng.2015.08.248

[23] Whittington J, Young S. Resilience through Transaction Cost Economic Evaluation: Recognizing the Cost-Effectiveness of Sustainable Development. Surv Perspect Integr Environ Soc. 2013;6(1):1-22.

[24] D.J.Yates, Greenwood DJ. The Determinants of Successful Partnering A Transaction Cost Perspective. J Constr Procure. 2006;12(1):4-22.

[25] Williamson OE. The economic institutions of capitalism: Firms, markets, relational contracting. Univ Illinois Urbana-Champaign's Acad Entrep Leadersh Hist Entrep [Internet]. 1985;61-75. Available from: http://amr.aom.org/cgi/doi/10.5465/AMR.1987.4308003

[26] Kissell R. Chapter 3. Algorithmic Transaction Cost Analysis [Internet] The Science of Algorithmic Trading and Portfolio Management. Elsevier Inc.; 2014. 87-128 p. Available from: http://dx.doi.org/10.1016/B978-0-12-401689-7.00003-9

[27] Dudkin G, Vailia T. Transaction Costs in Public-Private Partnerships: A First Look at the Evidence. EIB Econ Financ Rep [Internet]. 2005;(3):44. Available from: http://www.eib.org/efs/

[28] Soliño AS, Gago de Santos P. Transaction Costs in Transport Public-Private Partnerships: Comparing Procurement Procedures. Transp Rev [Internet]. 2010 May;30(3):389-406. Available from: http://www.tandfonline.com/doi/abs/10.1080/01441640903037941

\section{AUTHORS PROFILE}

My name is Toh Ka Bean, working with Department of Quantity Surveying, Universiti Teknologi Malaysia, Johor Bahru, Johor, 81310 MALAYSIA., kbtoh2@live.utm.my

Fara Diva Mustapa, my affiliation is Department of Quantity Surveying, Universiti Teknologi Malaysia, Johor Bahru, Johor, 81310 MALAYSIA.

My good name is Muzani Mustapa, luckly working with Department of Quantity Surveying, Universiti Teknologi Malaysia, Johor Bahru, Johor, 81310 MALAYSIA. 